\title{
The Speech of Dasein: Heidegger and Quotidian Discourse
}

\section{Alexander Gelley}

My point of departure is found in $§ 35$ of Sein und Zeit, where Martin Heidegger deals with Gerede, idle talk. His denunciation is so confident, so scathing:

And since this discoursing has lost the primary relation of being [Sein] to the being [Seienden] talked about, or else never achieved it, it does not communicate in the mode of a primordial appropriation of this being, but communicates by gossiping and passing the word along. What is spoken about as such spreads in wider circles and takes on an authoritative character. Things are so because one says so. Idle talk is constituted in this gossiping and passing the word along, a process by which its initial lack of grounds to stand on increases to complete groundlessness. (1949: 168) ${ }^{1}$

1. I follow this revision of the 1996 Stambaugh translation in accepting the spelling of "Dasein" throughout rather than "Da-sein." All page references to this work are to the German edition, which are also given in the margins of the English edition.

boundary $244: 2$ (2017) DOI 10.1215/01903659-3826636 C 2017 by Duke University Press 
What could Heidegger be talking about? It sounds so sinister and threatening. In looking for illustrations in literature, one could cite characters like Pecksniff or Mrs. Gamp (Martin Chuzzlewit) or Skimpole (Bleak House) or Podsnap (Our Mutual Friend) in Dickens, characters whose speech is very nearly an idiolect of bad faith, a model of inauthentic self-presentation. And yet there is something so fascinating and creative in their language, an exuberance in their dissimulation, that one wouldn't want to miss it. Or there is the confidence man in his multiple masquerades in Melville's great novel. But the list could go on and on.

How might Heidegger's category of Gerede be understood in relation to examples such as these? Could idle talk in Heidegger's sense contribute something to the theoretization of Mikhail Bakhtin's idea of the dialogic and heteroglossia, and to the notion of discours as it has been developed by Émile Benveniste, Roland Barthes, and Gérard Genette? What interests me especially is how language, in prose fiction, is valorized (often implicitly) as meaning/nonsense, serious/nonserious, full/empty. Bakthin's "carnivalization," Erich Auerbach's analysis of the transformation of the classical hierarchy of styles, Wlad Godzich and Jeffrey Kittay's idea of the "invention" (and repeated reinvention) of prose serve as helpful models for this kind of analysis. I want to pay particular attention to language that is deemed low, formulaic, or "empty"-gossip, chatter, prattle, idiotisms. When talk (discours) loses the thread of narrative, "nothing much" is said, but saying as act and process is foregrounded. It is this kind of inadvertence in language that I think of as its "idling" state. ${ }^{2}$

In literary usage, talk, speech, dialogue, and other such terms for oral articulation are, of course, conveyed in writing. The premise of narration is the enactment, or representation, of speech, a point that is implicit in the term discours in French narratology. But my focus is on a different issue, namely, the dividing line between thought and speech, reflection and verbal articulation.

Speech that is dissociated from thinking or reflection is usually valorized in a negative manner. Expressions like "(the mouth) running on," "blabbering," "stammering," "words gushing out," et cetera, suggest an impairment of speech that necessarily compromises the meaning. The norm of speech, its optimal exercise, assumes a priority of thought or reflection, as is indicated in expressions like "speaking deliberately," or "speaking

2. I have dealt with this issue in an essay focused on two works by Henry James, "In the Cage" and The Sacred Fount: see Gelley 2001. 
thoughtfully." Indeed, the traditional model of the derivation of speech is found in Aristotle's De Interpretatione: "Now spoken sounds are symbols of affections in the soul, and written marks symbols of spoken sounds" (1987: 12). ${ }^{3}$ Speech and writing are both classified here at the level of signs. For each there is a derivation from a prior modality, and in the case of speech this is located in the mind or soul. This model still governs Edmund Husserl's conception of voice in inner monologue in Logical Investigations, volume 1, as Jacques Derrida has demonstrated. Husserl here posits voice in a phenomenological sense, that is, (inner) voice as an inviolate source, which does not itself "mean" but which all acts of expression or articulation indicate or point to. Derrida has demonstrated how this constitutes a continuation of the long-standing link between voice and logos (1973: 15-16). What, then, is left for discourse? Is it to be understood as merely instrumental, the signs of a prior formulation in thought?

Heinrich von Kleist's text "On the Gradual Construction of Thoughts during Speech" ("Über die allmähliche Verfertigung der Gedanken beim Reden"), in a characteristically playful, paradoxical manner, illustrates the performative power of speech and puts forward a challenge to the traditional priority of thought over speech. The thesis is clearly stated right at the beginning:

If there is something you want to know and cannot discover by meditation, then, my dear, ingenious friend, I advise you to discuss it with the first acquaintance whom you happen to meet. He need not have a sharp intellect, nor do I mean you should question him on the subject. No! Rather you yourself should begin by telling it all to him.

I can see you opening your eyes wide at this and replying that in former years you were advised never to talk about anything that you do not already understand. In those days, however, you probably spoke with the pretentious purpose of enlightening others - I want you to speak with the reasonable purpose of enlightening yourself, and it is possible that each of these rules of conduct, different as they are, will apply in certain cases. The French say: l'appétit vient en mangeant and this maxim holds true when parodied into: l'idée vient en parlant. (1951: 42)

There follows then a series of anecdotes, each of which, in one way or another, demonstrates how, in a given situation, a speaker who had no

3. See Heidegger 1985 (242-43) for a discussion of this passage. 
clear idea what he was going to say, is so carried along by an association of words or ideas, or else by the reaction of an interlocutor, that he is led to a formulation that brings about a decisive change in the situation at hand.

In the context of Kleist's oeuvre, this text may be viewed as yet another demonstration ex negativo of the yearning in a postlapserian universe for the kind of innocence and spontaneity (Grazie in the language of "On the Marionette Theatre") that is associated with man's original, Edenic state. There is a recurrent pattern whereby Kleist represents the presence-absence, or rather the presence-as-absence in human existence of this state of grace. The axiomatic formulation of the underlying moral cosmogony is found in "On the Marionette Theatre": "We have eaten of the tree of knowledge. And Paradise is bolted with the cherub behind us; we must journey around the world and determine if perhaps at the end somewhere there is an opening to be discovered again" (1972: 24). The conclusion of the dialogue offers another version of this idea when one of the speakers in the dialogue asks, "Therefore ... would we again have to eat of the tree of knowledge to fall back again into a state of innocence?" (26; translation modified). It is worth noting here that the German, "in den Stand der Unschuld zurückzufallen," suggests something like a reverse fall, an undoing of the Fall, an "un-falling" into innocence. This point is relevant not so much for its theological or moral implications but as a pointer to a narrative or rhetorical practice that one finds recurrently in Kleist's writings.

In "On the Gradual Construction of Thoughts during Speech," Kleist develops a model of speech that is not merely instrumental but operates coordinately with thought for purposes of cognition and expression. At one point the narrator summarizes the issue as follows:

This kind of speech is nothing less than articulated thought. The chains of ideas and of their designations proceed together at the same speed, and the mental documents for the one and for the other agree. Then speech is not an impediment, a sort of brake on the wheel of intellect, but like a second wheel running parallel with it on the same axle.

It is quite a different matter when the mind has already finished off the thought before speech begins. For then the mind must pause at the mere expression, and this business, far from exciting it, has indeed no other effect than to provide relaxation from excitement. (1951: 44-45) 
The model of speech that Kleist develops here is akin to the idea of walking as a repeatedly arrested falling. Speech here is not subordinate to thought but the two are linked in a kind of intermittent coupling in which they alternately precipitate and retard one another. In one sense this is very much within the traditional model of the copresence of expression and meaning (Ausdruck and Bedeutung in Husserl) in the self. But the models Kleist puts forward in the anecdotes complicate the issue significantly. If there were a true parallelism between speaking and thinking (Sprache/Geist in Kleist's text), thinking would be complete in its inner, meditative state. But this clearly is not what the examples demonstrate. In fact, there is a lag, a displacement between the two, and it is this tension that serves as a means of excitation (Erregung) and as a stimulus for a continuing verbal articulation. "Lautes Denken" here is not to be understood as a simultaneity of speech and thought that resolves the dichotomy of present/past or presence/absence. Rather, what is involved is perhaps best likened to a form of associative thinking based on a structure of Nachträglichkeit in the sense that Derrida develops the Freudian notion, that is, of "a 'past' that has never been nor will ever be present, whose 'future' will never be produced or reproduced in the form of presence" (1973: 152).

In the examples that Kleist provides, idle talk serves as a means of gathering energy for purposes of a sudden release in action. The act itself has the quality of an inexplicable irruptive force. What Kleist illustrates is the diversionary talk that allows the irruption to occur. "I interpose inarticulate sounds, draw out the connecting words, possibly even use an apposition when required and employ other tricks which will prolong my speech in order to gain sufficient time for the fabrication of my idea in the workshop of reason" (1951: 42). One should not conclude that Kleist here is simply inverting the traditional priority of thought over speech. Rather, as Christian Strub rightly argues, the text develops "a different idea of the faculty of language, one in which speech is still the 'servant' of thought, but in the sense that language inhabits the current of speech not as a mere accessory but as the very ground of the thought" (1988: 286). This ground, however, Strub continues, should not be taken as a reliable basis for the communication of truth. The transmission of truth, for Kleist, is in principle uncertain and vacillating, ever subject to disturbance, to lapses into conventionality and dissimulation, and capable of succeeding only rarely through the intervention of a well-nigh miraculous good fortune.

While I am well aware that "On the Gradual Construction of Thoughts during Speech" offers a very restricted instance of idle talk, what makes this 
text relevant is that Kleist puts forward a conception of language that, like Heidegger's, bypasses a representational as well as an expressive model of language and focuses instead on a pragmatic or performative dimension, one that takes such performativity not simply as a consequence of the operation of language but as a foundational element. ${ }^{4}$

Let me now turn to Heidegger. In the Greek tradition, the basic epistemological terminology was related to sight, visuality. Heidegger does not ignore this, but he does not grant it exclusive preeminence either. The world in which man finds himself is not simply an out-there, to be apprehended as seen, but one that is already worked over in terms of human needs and projects. The "relation" of man and world cannot properly be termed "relation" at all since one cannot think a world separate from human existence nor, conversely, think human existence in isolation from its world. The early parts of Sein und Zeit are focused on this meshed fabric of availability that constitutes the being-in-the-world of Dasein. The notion of Erschlossenheit, disclosedness, is central to this argument.

For Heidegger, any idea of "mankind" or human existence is predicated on an originary form of access to a world. Dasein (being there), in-der-Welt-sein (being-in-the-world) -these formulations express the co-originary (gleichursprünglich) status of human existence and world. Dasein's being-in-the-world testifies both to the availability of world but also to Dasein's circumstantial (geworfen, thrown or outcast) status in the world, thrown or enmeshed in a situation that is not of its own making, a situation that Dasein did not create and thus cannot altogether master.

The twist or flexion in Heidegger's analysis is that, along with the disclosedness or availability of the world, there is also a closing or withdrawal. Not that phenomena are deceptive or inaccessible. Truth is predicated on a fundamental dis-closedness of reality, thus a-leitheia, un-concealedness (Heidegger 1949: 33). But the work of truth, its coming to light, involves a process in which the privative elements are as important as the positive or revelatory ones.

In addition to Dasein, there is another term for human existence,

4. Krzysztof Ziarek writes, "Benjamin and Heidegger propose models of language that might be called translational or transpositional. . . . They render the problem of representation secondary: they preempt, as it were, the issue of referentiality of language by extending the notion of language to the very event of manifestation, to phenomenality itself. ... In this view, the world is not only thought and experienced within language, that is, as always already transposed (translated) into language, but takes itself the form of a language event" (2001: 55). 
one that, in a sense, underscores the commonality-and also the commonness - of the human lot, and this is das Man, translated as "the they." There is something uncanny in Heidegger's German neologism that does not come across in English. In German, man and Mann, though identical in pronunciation, have quite different meanings. Mann is translated into English as "man" and would require a masculine article (der Mann). German man (not capitalized) is an impersonal pronoun that could signify either "one" or "they" (as in "they say" or "one says" or "people say"). As a pronoun, man is never used with an article. Thus, the locution das Man (with the capital, as if it were a noun) has the effect of a deformation of Mann, as if man (mankind) could be reduced to a level of impersonality.

To draw or extract a meaning from phenomena involves, in Heidegger's terms, a distinct and forcible process: "The way of encountering being and the structures of being in the mode of phenomenon," Heidegger writes, "must first of all be wrested [abgewonnen werden] from the objects of phenomenology" (36). What Heidegger terms "wresting" here involves a decisive feature of his conception of phenomenology, namely, that the meaning or sense (Sinn) of phenomena can become accessible only through an interplay of hiding and disclosure, and further, that this sense is unique to each phenomenon: "Essentially, nothing else stands 'behind' the phenomena of phenomenology. Nevertheless, what is to become a phenomenon can be concealed. And precisely because phenomena are initially and for the most part not given phenomenology is needed. Being covered up is the counterconcept to 'phenomenon' [Verdecktheit ist der Gegenbegriff zu 'Phänomen']" (36).

What I want to pursue now is how, within the argument of Sein und Zeit, language enters into the covering/uncovering process that Heidegger initially locates at the level of phenomenology. But in doing so, he is in no sense setting up an order of priority whereby a level of conception or perception is made antecedent to that of language. As Krzystof Ziarek writes, "The Heideggerian insight into language pivots upon the recognition of the already linguistic character of phenomenality, on the idea that manifestation is a form of a 'showing saying': 'The saying is by no means the supplementary linguistic expression of what shines forth; rather all shining and fading depend on the saying that shows'" (2001: 57)..$^{5}$ This citation is from "The Way to Language," written in 1959, but already in Sein und Zeit, which appeared in 1927, we read, "Discoursing [Reden] is the 'significant' articu-

5. The citation is from Heidegger 1993 (414). 
lation of the intelligibility of being-in-the-world" (Heidegger 1949: 161). Further, I want to clarify in what sense the issue of disclosure (covering/uncovering) is related to what will be the "entanglement," Verfall, of language in the everyday, Alltäglichkeit, which is, precisely, Gerede.

For this entanglement or lapse of signifying discourse, of language as speech, Rede, is not, as we will see, merely a feature of language but is the very condition of language, since the worldly is itself lapsed, fallen out of being and consigned to the status of beings in the world. "Initially, Dasein is the they and for the most part it remains so. If Dasein explicitly discovers the world and brings it near, if it discloses its authentic being to itself, this discovering of 'world' and disclosing of Dasein always comes about by clearing away coverings and obscurities, by breaking up the disguises with which Dasein cuts itself off from itself" (129).

To anticipate the argument: on the one hand, Gerede denotes a kind of defective mode of understanding, typical of the impersonal construct of the public subject that Heidegger terms "das Man," the they. Gerede is the medium for what is termed "alltägliche Ausgelegtheit" (the quotidian, routinized form of interpretation and explanation), which is the basis for Dasein's understanding of phenomena. But at the same time, consistent with the phenomenological principle enunciated above - that hiddenness is the counterconcept to phenomenon, to showing-forth-Gerede, in its very accessibility and commonness, may also serve as an opening to a dimension of being or truth.

Earlier I indicated that Dasein, the being-there of being-in-the-world, expresses the co-originary status of human existence and world. What is elided in this schema-what necessarily eludes determination-is precisely the what, that is, the content or substance of what is apprehended or exchanged in the coupling of human existence and world.

In the philosophical tradition, this element has been designated as Logos, a term that has been variously translated, Heidegger notes, as "reason, judgment, concept, definition, ground, relation" (32). What Heidegger foregrounds from this semantic network is a fusion of man's articulating capacity, ratio, with the power to apprehend, to see, apophainestai, letting something, "namely what is being talked about," be seen (32). These are co-originary, and constitute a prelingual, discursive disclosure of world for Dasein. Heidegger thus underscores the fact that articulation and manifestation are from the start indissoluble. What is disclosed (as world) has already been formulated, though only as the possibility of speech, not yet its concrete realization. 
This stage in the analysis of the language field is termed Rede, discourse, a term that may give rise to some confusion since it does not yet signify language as generally understood. Rather, it designates a prelingual, discursive disclosure of world for Dasein. It is only in a subsequent stage of the analysis that Rede attains to concrete realization, as language, Sprache, the phonic articulation in words, "stimmliche Verlautbarung in Worten" (32-33). "When fully concrete, speech [Rede] (letting something be seen) has the character of speaking [des Sprechens] or vocalization in words" (32).

What marks the threshhold between Rede and Sprache, between prelingual discourse and the articulation of language in words? This is a crucial moment in the derivation (construction) of Dasein since it leads from a stage of "primordial disclosedness of being-in-the-world" (160) to one that-we need to proceed cautiously here-is inescapably caught up, enmeshed in (Verfallen) "a specifically worldly mode of being" (161).

I am glossing here $\$ 34$ of Sein und Zeit, "Dasein and Discourse: Language." Heidegger remarks here, "Discourse is existentially equiprimordial with attunement and understanding" (161), but he notes also that this elucidation of discourse and language "only now becomes thematic." Thus, it is quite late in the argument, only after the treatment of the other two "fundamental existentials of the being of the there [Da]" of Dasein, namely, of attunement and understanding, that he turns to an explicit development regarding discourse. It is worth noting too that not only does the treatment of discourse and language come very late, but it also enters the argument as a derivative of the analysis of understanding. This derivation, which is worked out in §§32-33, is summarized at the beginning of §34: "An extreme derivative of interpretation was made visible with the statement. The clarification of the third meaning of statement [Aussage, assertion] as communication (speaking forth) led us to the concept of saying and speaking, to which we purposely paid no attention up to now. The fact that language only now becomes thematic should indicate that this phenomenon has its roots in the existential constitution of the disclosedness of Dasein" (160). I am laying stress on this derivation, on the way that discourse and language only gradually emerge in the argument, in order to show that although discourse, Rede, is thematized as an "existential," that is, as one of the three coordinate, originary ("equiprimordial") constituents of the disclosedness (Erschlossenheit) of Dasein, it could not be posited in itself as a foundational, grounding category. It had to be shown that discourse is always already implicated in understanding and attunement. 
Have we arrived at language yet? Hardly. The analysis of being-in, of the there, the $\mathrm{Da}$, in which Dasein is shown to have an opening, an access to worldly reality in $\S \S 29-33$, is notably lacking in any consideration of words, of language in its lexical and grammatical articulation. Yet there is meaning, there is an articulation that is termed "the totality of significations" (161), but so far there has been nothing like an endowment of speech, no words to attach to the significations made available to Dasein in the disclosure of world.

If we view Heidegger's ontology up to this point as a cosmology, we might say that he has given us a creation narrative but no origin of language, no "Namengebung" like Adam's in Genesis. There is, as it were, no pre-Babelic stage of language here. Language is from the start implicated in the state of "Verfall" of Dasein, not in the sense of the Christian Fall, but as a constitutive lapse, a falling into an entanglement with the world. Insofar as there is an origin of language in Heidegger's cosmogenesis, it is, in the following passage, both acknowledged and elided, "discourse must also essentially have a specifically worldly mode of being. The attuned intelligibility of being-in-the-world is expressed as discourse. The totality of significations of intelligibility is put into words. Words accrue to significations" (161).

"Words accrue to significations [Den Bedeutungen wachsen Worte $z u$ ]." What Heidegger seems to express in this formula is the radical immanence of language with regard to the referencing of the worldly. Heidegger thus bypasses the problematic of a representational conception with its necessity of accounting for the relation of language to its outside, in short, the problem of reference. As Martin Seel puts it, "The 'primary significations' are not given in the work of predication, but rather in being involved with something where this becomes important. It is from this significance, Heidegger argues, that words accrue to significations" (1992: 335). ${ }^{6}$

What I want to trace now is a kind of slippage that seems to take place as Heidegger, in §34, pursues the analysis of what happens to Rede in its "specifically worldly mode of being," that is as Sprache, as articulate

6. 'Das 'primäre Bedeuten' sei nicht in Leistungen der Prädikation gegeben, vielmehr in dem Zutunhaben mit etwas, worin dieses belangvoll werde. Aus dieser Bedeutsamkeit, lehrte Heidegger, wächst unseren Worten Bedeutung zu" (Seel 1992: 335). Matthew Rampley confirms this argument. "The significations of Rede... are both logically distinct from and prior to the lexical items of any language. For language is the mere medium of expression of Rede, rather than comprising any autonomous sphere of activity" (1994: 218). 
language. But to clarify what is happening, we would do well to revert briefly to an earlier section, $\S 33$ on Aussage (statement, assertion). This notion derives from understanding (by way of interpretation), one of the two fundamental existentials treated so far. (Stimmung, attunement is the other; Sprache will be a third.)

Heidegger distinguishes three elements in statement (Aussage): (1) pointing out (Aufzeigen), (2) predication, (3) communication (Mitteilung). The last introduces the dimension of hearing, listening to. And indeed, hearing, listening, will be "constitutive for discourse" in the subsequent discussion of Rede (163). This is not surprising when we recall the centrality of Mitdasein in §26: "The world of Dasein is a with-world" (118). In this sense, as Matthew Rampley notes, "meaning is never merely something produced by Dasein, but that which always already governs Dasein's encounter with the world" (1994: 220). It is noteworthy that in discussing the communicative dimension of statement, Aussage, in $\S 33$ Heidegger had prepared for a deviancy, a flaw in disclosure at the level of transmission. "What is spoken can be 'passed along' in further retelling . . . what is pointed out can become veiled again in this further retelling" (1949: 155).

How is this "passing along," this mutation in transmission, different from the complete rootlessness of Gerede as it is then to be characterized in $\S 35$ ? In fact, this characterization seems to be an intensification of "passing along," of hearsay. Once we have finished with the initial characterization of language, Sprache, we are reminded that "our interpretation has in a way lost sight of the everydayness of Dasein. ... Dasein [is] initially and for the most part immersed in the they and mastered by it" (167). And this launches us in the crucial, but in many ways puzzling, §34.

In this section, Heidegger calls for a fundamental reorientation of our approach to language, one that reaches back to a conception of logos antecedent to its formalization by way of logic and grammar. "The Greeks do not have a word for language, they 'initially' understood this phenomenon as discourse. However, since the logos came into their philosophical view predominantly as statement, the development of the fundamental structures of the forms and constituents of discourse was carried out following the guideline of this logos. Grammar searched for its foundation in the 'logic' of this logos" (165). Heidegger does not provide any historical evidence for what constituted an antecedent stage, but he does attempt to illustrate communication as a "fundamental constituent of Dasein ... the articulation of being-with-one-another understandingly" (162). In elaborating the notion of communication, he develops discourse (Rede) to encompass listening 
and hearkening (Hörenkönnen, Horchen) and provides highly differentiated examples: "'Initially' we never hear noises and complexes of sound, but the creaking wagon, the motorcycle. We hear the column on the march, the north wind, the woodpecker tapping, the crackling fire. It requires a very artificial and complicated attitude in order to 'hear' a 'pure noise'" (163). This kind of specification is rare in Sein und Zeit.

Gerede now is the first of a series of characteristics of the "durchschnittliche Verständlichkeit” (average, leveling intelligibility) (168), manifestations of the everydayness of spoken language. The others that are treated successively are curiosity and ambiguity. But it is the discussion of Gerede that is the most subtle and differentiated in this section. Often, in fact, the subsequent modalities of this "average intelligibility" are explicated in terms of Gerede, as with curiosity (173). It's as if a disease had overtaken Dasein's access to the world.

But even the way in which the term Gerede is introduced is somewhat curious. In its normal connotation, the word certainly has a negative, disparaging valence-hearsay, gossip, idle talk (Geschwätz is somewhat stronger, more condemning, more a sense of empty, debased speech). But Heidegger has prepared for his use of Gerede in $\S 35$ by a fourfold distinction regarding language in §34: (a) das Beredete, (b) das Geredete, (c) Mitteilung, (d) Bekundung. These are termed "konstitutive Momente" (constitutive factors) of Rede and are discussed in sequence (162). But the English version makes it hard to note the terminological differentiation.

(a) Das Beredete is "what is talked about"; Rampley writes that it "could equally well be translated as the 'referent'" (1994: 218).

(b) Das Geredete is "what is spoken as such" (Heidegger 2010: 162).

(c) Mitteilung is communication.

(d) Bekundung is what is "made known in discourse and indicated in language" (162).

Though each of these terms would warrant detailed treatment, it is the first two that concern us most. At this stage, the distinction between them might be understood as one between logical content (das Beredete) and grammatical form (das Geredete). In a sense, it could also be taken as replicating the distinction between Rede and Sprache. But the kind of falling off or flaw that Heidegger attaches to Gerede in $\S 35$ is not evident in this discussion of das Geredete in §34.

The earlier passage, where discourse (Rede) was characterized as the "putting into words" of "the totality of significations of intelligibility" (Hei- 
degger 1949: 161), seems to mark the step from das Beredete to das Geredete, but it is difficult to understand how this "putting into words" can lead to the kind of lapse or entanglement that will be assigned to Gerede. Yet that is just what Heidegger implies in §35.

"One understands not so much the beings talked about [das beredete Seiende], but one does listen to what is spoken about as such [das Geredete als solches]" (168). This is curious. Heidegger seems to be suggesting (as Rampley puts it) that "the function of statement [Aussage, assertion] as an expression of Being-in-the-world is being in a sense supplanted by the semantic structures of language, in other words das Beredete or the referent is covered up by the surface meaning of das Geredete" (Rampley 1994: 221). A bit further on this page of Heidegger's text, we read, "discoursing has lost the primary relation of being to the being talked about, or else never achieved it, it does not communicate in the mode of a primordial appropriation of this being, but communicates by gossiping and passing the word along" (Heidegger 1949: 168). Gerede now takes on a determinate, terminological valence in the argument, one that slips in, as it were, from a distinction that was never clearly argued, that between das Beredete (in the sense of the referent) and das Geredete ("what has been said or spoken" in idiomatic usage, with no sense of devaluation or flaw).

I have spent some time on this discussion of Gerede, but let me put it into the context of the larger argument at this point in Sein und Zeit. All three forms of the disclosedness of Dasein in its everydayness-idle talk, curiosity, ambiguity - are shown to be tributary to the disclosedness of the they, and the covering concept for this condition is das Verfallen, entanglement or falling prey. How is this locution to be understood?

"Dasein [is] initially and for the most part immersed in the they and mastered by it" (167). The implication here of a yielding, a ceding, supports Stambaugh's translation of "falling-prey" and "entanglement." One might be inclined to interpret the term in a moral or theological sense, but Heidegger is at pains to avoid such a connotation. Verfallen, he writes, "does not express any negative value judgment" (164). Eugen Fink, closely associated to Husserl but also a student of Heidegger, defined Verfallenheit as "an omission, a suspension of the 'transcendence' of human Dasein" (Fink 1976: 123). But such a suspension, Françoise Dastur argues, is not to be understood as a cancellation. "Dasein," she writes, "even in its 'inauthenticity' (its Uneigentlichkeit), its blindness with respect to the transcendence which it has, or rather, which it properly (eigentlich) 'is,' since it does not expressly bring it about, cannot cease to transcend without denying itself 
as Dasein" (Dastur 1988: 138; my translation). The idea that Dasein "cannot cease to transcend" points to an ongoing labor of negativity. Dasein's entanglement in the they (das Man), far from being an irreversible subjection, an exclusion from a sphere of truth or from an access to being, is the very condition of the possibility of disclosure, of Erschlossenheit.

Insofar as the everydayness, the quotidian existence, Dasein, is manifest as language, it is as Gerede and not as Logos, for Gerede partakes of the condition of lapse or "falling" (Verfall) that inheres in Dasein." If Dasein is to be taken as the condition of human existence in its everydayness, in the quotidian, and is constitutively in a state of Verfall, isn't every form of Dasein's expressive capacity, that is, everything that falls under Rede, or discourse, and not Gerede alone, necessarily also in that state? Or inversely, what justifies qualifying a register of language-precisely language as discourse in its everydayness, its typical attachment to Daseinas somehow deficient, not directly in touch with being? And yet, insofar as Gerede is subject to understanding and interpretation, is it not also susceptible to that opening up, that moment of disclosure, that leads to a more direct manifestation of Logos, to the un-hiddenness of a-leitheia?

If we go back to the lecture course on Aristotle that Heidegger gave in 1924, just prior to the appearance of Sein und Zeit, we find a treatment of Rede, in conjunction with Logos, Sprache, and Gerede, that aligns it clearly with the Greek sense of human existence (Dasein des Menschen) in the sense of zoon logon echon. Heidegger then continues, referring to his own time, "We do not have a corresponding definition. A more or less corresponding one would perhaps be, 'Man is a living creature who reads the newspaper'" (Heidegger 2002: 108; my translation). Here and in the following pages, Heidegger is intent on defining a level of ordinary human existence that would link the Greek experience with the contemporary. Rede, he writes, is not to be taken merely in a physiological sense but as an ontological component of human existence: "Man is a living being, whose true existence [Dasein] is manifest in speech and discourse [im Gespräch und in der Rede]." He then claims that "the Greeks were entangled by language. . . . The Greeks were altogether absorbed by the external. At the time of Plato and Aristotle Dasein was so wholly saturated with idle talk [Geschwätz] that it took the combined efforts of both to even attain a possibility to take scientific pursuits [Wissenschaft] seriously" (109). These

7. "Fallen" language as chatter, Geschwätz, has been treated by Fenves 1993 and Fenves 2001. See also Gelley 2015 (81-82, 142-44). 
remarks are, admittedly, in notes taken from lectures, and I do not suggest that they take precedence over the text of Sein und Zeit. But they may serve to confirm the discussion of Gerede in $§ 35$ of Sein und Zeit. Here the negative valorization of the Greeks' experience of language of the Aristotle lectures is applied to communication altogether, whether as speech or writing (Gerede, Geschreibe [1949: 168]), as the typical way of being interpreted (duschschnittlichen Ausgelegtheit [170]) or as the quotidian way of being interpreted (alltägliche Ausgelegtheit [169]) of the part of Dasein. It is communication wholly oriented to its articulation at the expense of the referent: "What is important to it is that one speaks. The being-said, the saying, the pronouncement provide a guarantee for the genuineness and appropriateness of the discourse and the understanding belonging to it" (168).

It is significant, too, that Gerede is "uprooted" (entwurzelt), "and this uprooting is constant. Ontologically, this means that when Dasein maintains itself in idle talk, it is, as being-in the-world, cut off from the primary and primordially genuine relations of being towards the world, toward Dasein-with, toward being-in itself. It keeps itself in suspension" (170). Now this "suspension," this "groundless floating" (177), is in no sense a vague or indeterminate condition above existence or the world. Rather, it is, as Jean-Luc Nancy argues, "the originary undecideability of being-thrown-in-the-world (to the 'they')" (Nancy 1993: 96). Nancy here alludes to the end of §34, where Heidegger returns to "the existential structures of the disclosedness of being-in-the-world," and specifically of "Dasein, as thrown being-inthe-world, initially thrown into the publicness of the they" (Heidegger 1949: 167). Here Nancy sees a possible discrepancy: the phrase "publicness of the they" indicates that "Dasein is opened to the 'they,' to which it is thrown as to its everyday world; this means . . . to a world of mediocre and 'inauthentic' banality from which Dasein should decide to extract itself. But the expression can also signify-and must signify, according to the deepest logic of analysis - that the 'they' carries disclosedness along with it, gives disclosedness, and even that it is, before everything else, the site of disclosedness" (Nancy 1993: 89). This double orientation of Dasein-at once trapped in the mediocrity of the they and open to its always available disclosedness - is the basis for the significance that Nancy attaches to "decision" (Entschlossenheit) in Sein und Zeit. Not a resolute act of assumption but something like "the activity of its passivity" (105) or of existence as "being determined according to indetermination, in such a way that, to be what it is, it must decide/reach its decision" (105).

One may wonder whether, in light of the covering/disclosing dynamic 
of Heideggerian phenomenology, the argument of $\S \S 34-35$ of Sein und Zeit puts forward an essentially negative valorization of Gerede. Admittedly, Heidegger sought to avoid such a valorization when he wrote, "The expression 'idle talk' [Gerede] is not to be used here in a 'disparaging' sense. Terminologically, it means a positive phenomenon which constitutes the mode of being of the understanding and interpretation of everyday Dasein's" (167). But this did not prevent comments like that of Michael E. Zimmerman: "In reading Section B [of chap. 5], I find that Heidegger is speaking not about average disclosedness but about inauthentic disclosedness. . . . Idle talk is the ideology of everydayness and inauthenticity" (1986: 53, 57). While such a statement could be supported by certain passages in Heidegger's text, an approach like Zimmerman's stresses the opposition of inauthentic/authentic and gives Heidegger's analysis of Dasein in its everydayness an ethical and existential slant that does not give due weight to the rhetorical issues at play. What I have tried to show is that the valorization of Gerede (and of Neugier and Zweideutigkeit) does not consist in anything like an explicit judgment but emerges from the complex, circuitous formation of concepts relating to speech and language in Sein und Zeit.

It may help to view the issue that Heidegger raises with respect to the coordinate manifestations of Dasein's being-in-the-world in the context of language as "a form of life" in Ludwig Wittgenstein's sense: "So you are saying that human agreement decides what is true and what is false?'-It is what human beings say that is true and false; and they agree in the language they use. This is not agreement in opinions but in the form of life" (1958: §241). Admittedly, this introduces a dimension quite foreign to what is generally understood as Heidegger's thought, but it seems to me that the claims of Sein und Zeit, and notably, in its treatment of speech and language, should be open to this. The kind of agreement that Wittgenstein refers to has been glossed by Stanley Cavell: "The idea of agreement here is not that of coming to or arriving at an agreement on a given occasion, but of being in agreement throughout, being in harmony. . . . That a group of human beings stimmen in their language überein says, so to speak, that they are mutually voiced with respect to it, mutually attuned top to bottom" (Cavell 1979: 32). This seems quite consistent with Heidegger's analysis in $\S 29$ of the way that Dasein's being-in-the-world is grounded in attunement and mood (Befindlichkeit, Stimmung).

What I have attempted is, in a sense, a heuristic reading of the "lapse" or entanglement of Dasein, one that seeks to situate the place of Gerede in Dasein's sense-making capacity. In foregrounding this potential 
of Gerede-one that is based on the covering/uncovering mode of Erschlossenheit and of truth as a-leitheia-I realize that I am drawing out an implication of Sein und Zeit that in part runs counter to its explicit argument and, even more, to Heidegger's later work on language, where he will look to art to provide a means for the disclosure of truth by way, for example, of an opening (in a forest), a "lighting" (Lichtung).

Maurice Blanchot, in an essay on Louis-René des Forêts's Le Bavard, a novel that seeks to systematically dramatize the practice of idle talk (bavardage), provides this revealing commentary:

In truth, everyone indulges in idle talk [bavarde] but everyone condemns idle talk [bavardage]. Adults say it to children: you're just prattling; just as the male says it to the female, the philosopher to the ordinary man, the politician to the philosopher: bavardage. This reproach stops everyone in their tracks. I have always been struck by the intense and admiring approbation that has been universally accorded to Heidegger when, under the pretext of conducting an analysis and in his characteristic sober and forceful manner, he condemns inauthentic speech-despicable speech that is never that of the resolute, laconic, and heroic "l" but the non-speech of the irresponsible "they." They speak, which is to say, no one speaks. Which is to say, we live in a world where there is speech without a speaking subject, a civilization of speakers without speech, aphasic prattlers, reporters who report without declaring themselves, technicians without name or the power of decision. This discredited speech encloses within the discredit which is directed at it the judgment which one makes of it. He who considers another a bavard renders himself suspect of a worse bavardage, pretentious and authoritarian. The appeal to seriousness, which requires that one speak only with due deliberation and gravity, or else that one not speak at all or only begin to speak, soon reveals itself as an attempt to close off language. It's a matter of arresting words under the pretext of giving them back their dignity. One imposes silence by, oneself, denying the right to speak. One denounces empty talk and substitutes for it the cutting word which does not talk but commands. (Blanchot 1971: 145-46; my translation)

Blanchot does not enter in detail into Heidegger's position, though he is alert to its equivocal stance. He goes on, in a vein quite independent of Heidegger, to examine the insidious power of idle talk-its power to "close off 
language," to deny "the right to speak," and, for all its hollowness, to impose and command.

It's true that, in terms of the architectonic plan of Sein und Zeit, the interpretation of Dasein in its everydayness in Division 1 is provisional and leads to the analysis that comes in Division 2. In this later part, the distortion, the constitutive self-misinterpreting of Dasein that was presented in a "preparatory" manner in Division 1 is subjected to a more rigorous analysis guided by the category of temporality. Nonetheless, Heidegger in no sense claims that Sein und Zeit will provide a means of redeeming Dasein from its state of worldly entanglement. Thus he writes, "Dasein can never escape the everyday way of being interpreted into which Dasein has grown initially. All genuine understanding, interpreting and communication, rediscovery and new appropriation come about in it and out of it and against it" (Heidegger 1949: 169). In this sense, I argue that Gerede, in its very negativity, is not to be understood as an aberration, a lapse from some supposed positivity, but as a component of the systematic entanglement of Dasein's being-in-the-world.

\section{References}

Aristotle. 1987. A New Aristotle Reader. Edited by J. L. Ackrill. Princeton, NJ: Princeton University Press.

Blanchot, Maurice. 1963. "La Parole vaine" ("The Vanity of Speech"). In La Bavard, edited by Louis-René des Forêts. Paris: Gallimard.

1971. "La Parole vaine" (“Empty Talk”). In L’Amitié, 137-49. Paris: Gallimard.

Cavell, Stanley. 1979. The Claim of Reason. Wittgenstein, Skepticism, Morality, and Tragedy. New York: Oxford University Press.

Dastur, Françoise. 1988. "La fin de la philosophie et l'autre commencement de la pensée." In Heidegger: Questions ouvertes, by Collège international de phiIosophie, 125-41. Paris: Editions Osiris.

Derrida, Jacques. 1973. Speech and Phenomena. Translated by David B. Allison. Evanston, IL: Northwestern University Press.

Fenves, Peter. 1993. "Chatter": Language and History in Kierkegaard. Stanford, CA: Stanford University Press.

2001. "The Paradisal Epochē: On Benjamin's First Philosophy." In Arresting Language: From Leibniz to Benjamin, 174-226. Stanford, CA: Stanford University Press.

Fink, Eugen. 1976. Nähe und Distanz. Freiburg, Munich: Alber.

Gelley, Alexander. 2001. "Idle Talk: Scarcity and Excess in Literary Language." In Talk, Talk, Talk: The Cultural Life of Everyday Conversation, edited by S. I. Salamensky, 49-62. New York: Routledge. 
2015. Benjamin's Passages: Dreaming, Awakening. New York: Fordham University Press.

Heidegger, Martin. 1949. Sein und Zeit. Tübingen: Neomarius Verlag. . 1985. "Der Weg zur Sprache." In Gesamtausgabe 12: Unterwegs zur Sprache, 227-57. Frankfurt a.M.: Klostermann.

1993. "The Way to Language." In Basic Writings, edited by David Farrell Krell, 393-426. New York: HarperCollins.

2002. Grundbegriffe der Aristotelischen Philosophie. Vol. 18. Frankfurt/M: Vittorio Klostermann.

2010. Being and Time. Translated by Joan Stambaugh, revised by Dennis J. Schmidt. New York: SUNY Press.

Kleist, Heinrich von. 1951. "On the Gradual Construction of Thoughts during Speech." Translated by Michael Hamburger. German Life and Letters 5, no. 1: 42-46. www.ias-research.net/wp-content/uploads/2012/01/Kleist-and-Hamburger _-_1951_-_On-the-Gradual-Construction-of-Thoughts-During-Speech.pdf. 1972. "On the Marionette Theatre." Translated by Thomas G. Neumiller. The Drama Review: TDR 16, no. 3: 22-26.

Nancy, Jean-Luc. 1993. "The Decision of Existence." In The Birth to Presence, translated by Brian Holmes and Others, 82-109. Stanford, CA: Stanford University Press.

Rampley, Matthew. 1994. "Meaning and Language in Early Heidegger: From Duns Scotus to Being and Time." Journal of the British Society for Phenomenology 25, no. 3: 209-28.

Seel, Martin. 1992. "Sprache bei Benjamin und Heidegger." Merkur 46: 333-40.

Strub, Christian. 1988. “'Blosse Ausdrückung' und 'lautes Denken'. Zu Kleists Aufsatz 'Über die allmähliche Verfertigung der Gedanken beim Reden.” Kodikas/Code 11, nos. 3/4: 273-94.

Wittgenstein, Ludwig. 1958. Philosophical Investigations. 3rd ed. New York: Macmillan.

Ziarek, Krzysztof. 2001. "Reproducing History: Benjamin and Heidegger on the Work of Art in Modernity." In The Historicity of Experience: Modernity, the AvantGarde, and the Event, 33-85. Evanston, IL: Northwestern University Press.

Zimmerman, Michael E. 1986. Eclipse of the Self: The Development of Heidegger's Concept of Authenticity. Athens and London: Ohio University Press. 
Published by Duke University Press 